$\xi=$ 离

\title{
Annona muricata prevent hepatic fibrosis by enhancing lysosomal membrane stability and suppressing extracellular matrix protein accumulation
}

\author{
Usunobun Usunomena ${ }^{1 *}$, Okolie P. Ngozi ${ }^{2}$ \\ ${ }^{1}$ Department of Basic Sciences (Biochemistry Unit), Faculty of Basic and Applied Sciences, \\ Benson Idahosa University, P.M.B. 1100, Benin City \\ ${ }^{2}$ Department of Biochemistry, Faculty of Life Sciences, University of Benin, Benin City \\ *Corresponding authorE-mail:uusunobun@biu.edu.ng
}

\begin{abstract}
Background: Hepatic fibrosis is a pre-pathologic state of cirrhosis, which plays a pivotal role in the pathogenesis of hepatocellular carcinoma (HCC). This study was carried out to evaluate the hepatoprotective effect of Annona muricata leaves on extracellular matrix (ECM) accumulation, lysosomal membrane integrity and liver damage in dimethylnitrosamine (DMN)-induced fibrotic rats.

Methods: Healthy adult male wistar rats were divided into four groups. Group I rats received normal saline and served as control, Group II rats were administered 200mg/kg Annona muricata, Group III received 200mg/kg Annona muricata orally simultaneously with $10 \mathrm{mg} / \mathrm{kg}$ DMN, Group IV received $10 \mathrm{mg} / \mathrm{kg}$ DMN without extract. DMN administered intraperitoneally was on first three days of each week for two weeks while Annona muricata was administered for 14 consecutive days. 24 hours after last administration, all animals were sacrificed and blood collected for serum analysis. Biochemical parameters such as lactate dehydrogenase (LDH), total bilirubin (TB), total protein (TP), and albumin (ALB) were estimated to assess liver function and synthetic ability while hyaluronic acid (HA) was determined to assess extracellular matrix (ECM) function. In addition, acid phosphatase (ACP) was estimated to assess lysosomal membrane stability/fragility.

Results: Liver damage, decreased synthetic ability, lysosomal membrane fragility and altered ECM function were evident by an increase in the levels of LDH, TB, ACP and HA as well as a decrease in level of TP and ALB in sera of rats administered DMN compared to normal rats. However, simultaneous treatment with Annona muricata leaf extract significantly $(\mathrm{p}<0.05)$ reversed alterations in the above indices.

Conclusion: This study suggests that Annona muricata leaf functions as a potent fibrosuppressant by suppressing ECM accumulation, enhancing lysosomal membrane stability and liver synthetic ability.
\end{abstract}

Keywords: Annona muricata; Dimethylnitrosamine; Extracellular matrix; Fibrosis; Liver

\section{Introduction}

Hepatic fibrosis is the accumulation of extracellular matrix proteins (such as collagen and hyaluronic acid), or scar, in response to acute or chronic liver injury (George and Stern, 2004). The pathogenesis of hepatic fibrosis is mediated through oxidative stress and hepatocyte injury and is always accompanied by impaired hepatic metabolism and deposition of connective components, especially collagen and hyaluronic acid in the liver (Usunobun et al., 2015b; George and Stern, 2004).

Research on Annona muricata has shown that a novel set of phytochemicals (Annonaceous acetogenins) found in the leaves, seeds and stem are cytotoxic against various cancer cells (Chang, 2001; Liaw et al., 2002). Traditionally, Annona muricata leaves are used for headaches, insomnia, cystitis, liver problems, diabetes, hypertension and as an anti-inflammatory, anti-spasmodic and antidysenteric (Di-Stasi and Hiruma-Lima, 2002; Sousa et al., 2004; Taylor, 2002). Many bioactive compounds and phytochemicals, including flavonoids have been found in Annona muricata leaves (Usunobun et al., 2015; Usunobun and Okolie, 2015). Thus, this investigation was undertaken to evaluate the hepatoprotective activities of ethanolic leaf extract of Annona muricata against liver synthetic activities, lysosomal membrane fragility and extracellular matrix function in DMN-induced fibrotic male rats.

\section{Materials and methods}

\subsection{Collection, identification and preparation of annona muricata leaves}

Fresh leaves of Annona muricata were collected from the tree in Upper Sakponba, Benin City, Edo state, Nigeria and identified by a Botanist in the Department of Basic Sciences, Faculty of Basic and Applied Sciences, Benson Idahosa University, Benin city, Edo State. The Annona muricata leaves were separated from the stalk, washed and air-dried at room temperature $\left(24^{\circ} \mathrm{C}\right)$ and then pulverized, crushed into fine powder and weighed.

\subsection{Preparation of leaf extract}

The ethanolic extract of the plant leaves was prepared by soaking $300 \mathrm{~g}$ of the dry powdered plant leaves in $1000 \mathrm{ml}$ of absolute etha- 
nol at room temperature for $48 \mathrm{hrs}$ (for thorough extraction). The extract was then filtered first through a Whatmann filter paper No. $42(125 \mathrm{~mm})$ and then through cotton wool. The extract was thereafter concentrated in a rotary evaporator at $60^{\circ} \mathrm{C}$ to one-tenth its original volume and then finally freeze-dried. The dried residue (crude extract) was then stored at $4^{\circ} \mathrm{C}$. Portions of the crude extract were weighed and dissolved in distilled water for use on each day of our experiments.

\subsection{Experimental animals, DMN and extract admin- istration}

Male Albino Wistar rats weighing 150-225 g were obtained from the Animal Unit of the University of Ibadan, Ibadan, Oyo state, Nigeria. The animals were housed in controlled environmental conditions (temperature $-24 \pm 2{ }^{\circ} \mathrm{C}$; relative humidity $-50-70 \%$; $12 \mathrm{~h} \mathrm{light/dark} \mathrm{cycle)} \mathrm{in} \mathrm{the} \mathrm{Animal} \mathrm{House} \mathrm{of} \mathrm{the} \mathrm{Department} \mathrm{of}$ Biochemistry, University of Benin, Benin city, Edo state. The animals were provided standard pellet diet and water ad libitum. Institutional Animal Ethical Committee permission was obtained before performing the experiments. The DMN used in this work was synthesized according to the method of Vogel (1971).

Forty-eight (48) rats divided into four groups were used for the study. The Annona muricata leaf extract was reconstituted in distilled water and administered orally via gastric intubation to groups 2 and 3 rats at a dose of $200 \mathrm{mg} / \mathrm{kg}$ for two weeks ( 14 consecutive days). One of these groups (group 3) received DMN in addition at a dose of $10 \mathrm{mg} / \mathrm{kg}$ b.w (dissolved in $0.15 \mathrm{M} \mathrm{NaCl}$ ) via intraperitoneal injection in the first three days of each week for two weeks. Rats in group 4 received the same amount of DMN but without extract, while members of group 1 received normal saline and served as controls. Hepatic fibrosis was confirmed two weeks after through histology and total collagen assay (Usunobun et al., 2015b). Administration of extract and drug was between 9:00 10:00am each day. 24 hours after the end of the treatment period, the rats were sacrificed by cardiac puncture and blood collected via the ocular vein in plain tubes and allowed to stand for $45 \mathrm{~min}$ before centrifuging at 5,000 rpm for $20 \mathrm{~min}$. The serum samples were stored at $-20^{\circ} \mathrm{C}$ until analyzed.

\subsection{Biochemical assays}

Serum total protein, albumin, total bilirubin and lactate dehydrogenase were determined using RANDOX Kit according to the manufacturer's instructions. Serum Hyaluronic acid (HA) level was estimated using Biotech Trading Partners hyaluronic acid ELISA assay kit according to the manufacturer's procedure as described by Chichibu et al (1989). Serum acid phosphatase (ACP) activity was estimated using BIOSYSTEMS ACP assay kit according to the procedure suggested by the manufacturer.

\subsection{Statistical analysis}

Numerical data obtained from the study were expressed as mean \pm SD. Differences between means were determined using Statistical Package for Social Sciences (SPSS). A probability level of less than $5 \%(\mathrm{p}<0.05)$ was considered significant.

\section{Results}

Administration of DMN to rats produced significant increases in the serum levels of HA, ACP, LDH, total bilirubin and a significant decrease in total protein and albumin as shown in table 1 and 2. Simultaneous administration of ethanolic leaf extract of Annona muricata produced significant decreases in the activities of the serum extracellular matrix protein, lysosomal membrane enzyme and total bilirubin, while an increase was observed in the total protein and albumin levels compared to the DMN alone rats.
Table 1: Effect of Annona muricata on Serum Hyaluronic Acid (HA), Acid Phosphatase (ACP) and Lactate Dehydrogenase (LDH) in DMNInduced Hepatic Fibrotic Rats.

\begin{tabular}{llll}
\hline Treatment groups & HA $(\mathrm{ng} / \mathrm{ml})$ & ACP $(\mathrm{U} / \mathrm{l})$ & LDH $(\mathrm{U} / \mathrm{l})$ \\
\hline $\begin{array}{l}\text { Control } \\
\text { AME alone }\end{array}$ & $64.59 \pm 6.78^{\mathrm{a}}$ & $29.99 \pm 0.99^{\mathrm{a}}$ & $200.00 \pm 4.55^{\mathrm{a}}$ \\
$\begin{array}{l}(200 \mathrm{mg} / \mathrm{kg}) \\
\text { AME }(200 \mathrm{mg} / \mathrm{kg})+\end{array}$ & $64.20 \pm 5.17^{\mathrm{a}}$ & $28.42 \pm 8.50^{\mathrm{a}}$ & $\begin{array}{l}203.67 \pm 4.99 \\
\mathrm{a}\end{array}$ \\
$\begin{array}{l}\text { DMN }(10 \mathrm{mg} / \mathrm{kg}) \\
\text { DMN }\end{array}$ & $191.13 \pm 8.44^{\mathrm{b}}$ & $50.64 \pm 5.91^{\mathrm{b}}$ & $318.83 \pm 9.97^{\mathrm{b}}$ \\
alone $(10 \mathrm{mg} / \mathrm{kg})$ & $450.54 \pm 8.58^{\mathrm{c}}$ & $89.02 \pm 8.42^{\mathrm{c}}$ & $560.27 \pm 10.73^{\mathrm{c}}$ \\
\hline
\end{tabular}

Values are means $\pm \mathrm{SD} ; \mathrm{n}=5, \mathrm{AME}=$ Annona muricata ethanolic extract, $\mathrm{DMN}=$ Dimethylnitrosamine, HA =Hyaluronic acid, ACP = Acid phosphatase, $\mathrm{LDH}=$ Lactate dehydrogenase

Mean values in each column having different superscript (a, b, c) are significantly different $(\mathrm{p}<0.05)$.

Table 2: Effect of Annona muricata on Serum Total Protein, Albumin and Total Bilirubin in DMN-Induced Hepatic Fibrotic Rats.

\begin{tabular}{llll} 
Groups & $\begin{array}{l}\text { Total protein } \\
(\mathrm{g} / \mathrm{l})\end{array}$ & $\begin{array}{l}\text { Albumin } \\
(\mathrm{g} / \mathrm{l})\end{array}$ & $\begin{array}{l}\text { Total Bilirubin } \\
(\mathrm{mg} / \mathrm{dl})\end{array}$ \\
\hline $\begin{array}{l}\text { Control (normal } \\
\text { saline) }\end{array}$ & $62.90 \pm 3.62^{\mathrm{a}}$ & $33.93 \pm 0.14^{\mathrm{a}}$ & $0.59 \pm 0.02^{\mathrm{a}}$ \\
$\begin{array}{l}\text { AME } \\
\text { alone }(200 \mathrm{mg} / \mathrm{kg})\end{array}$ & $63.90 \pm 1.13^{\mathrm{a}}$ & $35.86 \pm 2.29^{\mathrm{a}}$ & $0.66 \pm 0.14^{\mathrm{a}}$ \\
$\begin{array}{l}\text { AME }(200 \mathrm{mg} / \mathrm{kg})+ \\
\text { DMN }(10 \mathrm{mg} / \mathrm{kg})\end{array}$ & $56.33 \pm 3.68^{\mathrm{b}}$ & $30.73 \pm 1.16^{\mathrm{b}}$ & $1.08 \pm 0.06^{\mathrm{f}}$ \\
$\begin{array}{l}\mathrm{DMN} \text { alone } \\
(10 \mathrm{mg} / \mathrm{kg})\end{array}$ & $31.81 \pm 2.86^{\mathrm{d}}$ & $15.48 \pm 1.08^{\mathrm{d}}$ & $2.91 \pm 0.39^{\mathrm{d}}$
\end{tabular}

Values are means \pm SD; $\mathrm{n}=5$, AME = Annona muricata ethanolic extract, $\mathrm{DMN}=$ Dimethylnitrosamine.

Mean values in each column having different superscript (a, b, c, d) are significantly different $(\mathrm{p}<0.05)$

\section{Discussion}

Fibrosis is a dynamic process that may result in increased circulating levels of extracellular matrix (ECM) including total collagen and hyaluronic acid. Hyaluronic acid is a polymer composed of repeating dimeric units of glucuronic acid and $\mathrm{N}$-acetylglucosamine. In the liver, hyaluronic acid is mainly synthesized by the stellate cells present in the sinusoidal areas (Vrochides et al., 1996). Increased serum Hyaluronic acid has been suggested as a sensitive marker and a diagnostic tool for hepatic fibrosis (Hasegawa et al., 2000; George and Stern, 2004; Stickel et al., 2001). It has also been reported that the elevated plasma levels of hyaluronic acid indicate endothelial cell dysfunction in the initial stages of alcoholic liver disease in rats (Nanji et al., 1996).

In this study, there was a significant increase in serum hyaluronic acid which could be explained by the increased synthesis of hyaluronic acid by activated stellate cells and simultaneous spillage into the blood stream along with AST, ALP and ALT during massive hepatic necrosis and thickened collagen fiber deposition as we showed in a previous report (Usunobun et al., 2015b). Since hepatic stellate cells are responsible for the synthesis of hyaluronic acid in liver (Patel et al., 2003; Vrochides et al., 1996), the stellate cell activation and proliferation during fibrogenesis would have triggered an increased expression of hyaluronic acid. Sinusoidal endothelial cells lack a basement membrane and hence, are permeable to molecules moving into hepatocytes. In the presence of fibrosis, the sinusoidal endothelial cells become thickened which is less permeable, so hyaluronic acid clearance is impaired and serum levels rise. Fibrosis also stimulates hepatic mesenchymal cells, so more hyaluronic acid is produced. In a study by Wyatt et al (2002) involving children with cystic fibrosis with biochemical or radiological evidence of liver disease, hyaluronic acid levels were also raised. Also Nyberg et al (1988) showed that hyaluronic acid levels are a sensitive tool that can be used to determine the degree of progressive liver injury in patients with primary biliary cirrhosis. Fried et al (2001) also showed that patients who developed liver fibrosis from chronic veno-occlusive diseases are also presented with elevated hyaluronic levels. Other similar studies involving patients with hepatitis $\mathrm{C}$ also revealed a direct correla- 
tion between fibrosis in liver biopsies and elevated hyaluronic acid levels (Halfon et al., 2005; Skripenova et al., 2007).

In this study however, simultaneous treatment of Annona muricata $(200 \mathrm{mg} / \mathrm{kg})$ erased the DMN intoxication and hyaluronic acid contents significantly decreased $(\mathrm{p}<0.05)$ compared to DMNalone administered fibrotic rats. It is possible Annona muricata leaves inhibited serum inhibitors of hyaluronidase by activating hyaluronidase, a hyaluronic acid degrading enzyme. The protection conferred could be due to presence of bioactive compounds such as acetogenins, flavonoids, alkaloids, saponins, tannins and vitamin C in Annona muricata leaves (Usunobun and Okolie, 2015; Usunobun et al., 2015). In a related study by Yacout et al (2012), on the hepatoprotective effect of Ocimum basilicum on $\mathrm{CCl}_{4}$-induced liver fibrosis in rats, Ocimum basilicum significantly reduced the content of hyaluronic acid by increasing the activity of hyaluronidase.

The stability and integrity of lysosomal membrane is important to maintain normal levels of lysosomal enzymes in tissues and body fluids. An increase in serum acid hydrolases, has been reported in a number of pathological conditions such as arthritis (Sandya et al, 2007) and myocardial infarction (Rajadurai and Prince 2007) and Hansen`s disease (Nandan et al, 2007). Acid phosphatase (ACP) is considered to be a marker enzyme of lysosomal membrane (Collins and Lewis, 1971, Akanji et al., 2008). In this study, there was a significantly increased level of ACP in the serum of DMNtreated rats compared to control and extract treated rats. The rise in serum ACP suggests hepatocellular necrosis and lysosomal membrane damage due to decreased liver membrane stability/increased membrane fragility and enhanced lipid peroxidation. ROS generated by Metabolites of DMN activation may have reacted with lipid bilayer of intracellular organelles including lysosomes, destabilizing lysosomal membrane and resulting in rupture of lysosomes. The result of the increase in ACP in this study is similar to that of Premila (2004) who reported that lysosomal enzymes such as ACP may contribute to cell death and tissue damage which are probable consequences leading to cirrhosis. However, treatment of rats with $200 \mathrm{mg} / \mathrm{kg}$ Annona muricata (AME) simultaneously with DMN significantly decreased ACP activity by its inhibitory effect on lipid peroxidation and stabilization of liver lysosomal membrane, thereby preventing DMN-induced lysosomal damage.

Monitoring activity of lactate dehydrogenase (LDH) is often selected as a marker for liver-induced injury. The result of this study showed significant increases $(\mathrm{P}<0.05)$ in serum LDH activity in $\mathrm{DMN}$-induced rats compared to control and extract treated rats similar to previously published reports (George and Chandrakasan 1997; Ahmad et al., 2009). The increase in LDH levels is a consequence of tissue injury and necrosis leading to leakage of the enzyme into blood stream. The significant loss of lactate dehydrogenase (LDH), an enzyme associated with the cytosol is quite understandable since it is in close proximity to the plasma membrane. However, simultaneous treatment of rats with DMN and Annona muricata caused a significant decrease in LDH activity compared to DMN-alone injected rats. This decrease in LDH activity suggests the protective effects of Annona muricata against loss of membrane integrity. In a related study by Ahmad et al (2009), Operculina turpethum attenuated serum LDH activity in DMN-treated rats. Muthulingam et al (2010) also reported decreased LDH activity in a study on the antihepatotoxic efficacy of Indigofera tinctoria on paracetamol-induced liver damage in rats. On liver synthetic ability, data of the present study showed that DMN administration produced a significant reduction in total protein and albumin serum levels similar to other findings (George et al., 2001; Qing-Wei and Geng-Tao, 2006; Ajmire et al 2011). The reduction in serum total protein and albumin levels may be due to loss of protein either by reduced protein synthesis or increased proteolytic activity or degradation. The catabolism may be due to the extreme centrilobular necrosis of the liver tissue during hepatic fibrosis as we have previously showed increased spillage of AST, ALT and ALP into serum as a result of intermittent DMN liver damage (Usunobun et al., 2015a, b). Also the reduction in total serum proteins observed in the DMN treated group may be associated with the decrease in the number of hepatocytes which in turn may result in decreased hepatic capacity to synthesize protein.

However, simultaneous administration of ethanolic leaf extracts of Annona muricata resulted in significant suppression of DMNinduced adverse effects on total protein and albumin levels, compared to DMN alone rats, suggesting that this plants have antioxidant activity based on maintenance of protein metabolism in the liver tissue in rats. The increase of total protein and albumin levels by Annona muricata (AME) compared to DMN alone rats indicate hepatoprotective activity as stimulation of protein synthesis accelerated the regeneration process and the protection of liver cells. In a related study by Shin and Moon (2010), DMN-induced decrease in serum albumin and total protein levels was significantly ameliorated by grape skin or seeds ingestion.

Also in this study, the hyperbilirubinaemia observed due to intermittent DMN administration may have resulted from the decrease of liver uptake, conjugation or increase bilirubin production from hemolysis, a finding which coincided with the decrease in total erythrocyte counts. The increase in serum total bilirubin may also be due to inflammation in the portal triads and/ or necrotic hepatocytes. However, treatment of rats with AME simultaneously with DMN significantly decreased total bilirubin compared to DMNinduced fibrotic rats thus suggesting that AME could help treat jaundice by offering protection on the liver, improving its bilirubin conjugating property and helping clear bilirubin from circulation. The mechanisms of action could be that AME activated Constitutive Andostane Receptor (CAR), a key regulator in the bilirubin clearance pathway (Huang et al, 2003), increasing the activity of glucuronyl transferases (Ostrow et al., 2003), synthesis of ligandin, a transporter of bilirubin, increasing its transport to the liver for conjugation (Greige-Gerges et al., 2007). Also the extract could have inhibited haem oxygenase activity, bilirubin pathway rate limiting enzyme. Our result in this study is in consonance with the findings of Arthur et al (2012) where carbon tetrachloride and acetaminophen-induced total bilirubin were ameliorated by treatment with aqueous extracts of Annona muricata leaves.

In conclusion, 14-day Annona muricata leaf administration at pharmacological doses proved to be effective against liver damage in a DMN-induced liver fibrosis model most probably due to the plants antioxidant and anti-inflammatory properties.

\section{References}

[1] Ahmad R, Ahmed S, Khan NU \& Hasnain A (2009). Operculina turpethum attenuates $\mathrm{N}$-nitrosodimethylamine induced toxic liver injury and clastogenicity in rats. Chemical and Biological Interaction 181, 145-53. http://dx.doi.org/10.1016/j.cbi.2009.06.021.

[2] Ajmire PV, Chidambaranathan N, Dewade DR, Narkhede MB, \& Wagh AE (2011). Effect of Boerhaavia diffusa against Dimethylnitrosamine induced liver cirrhosis. International Journal of Pharmacy and Pharmaceutical Sciences, 3(5), 366-370

[3] Akanji MA, Nafiu MO \& Yakubu MT (2008). Enzyme Activities and Histopathology of Selected Tissues in Rats Treated with Potassium bromate. African Journal of Biomedical Research 11, 87 - 95.

[4] Arthur FKN, Woode E, Terlabi EO \& Larbie C (2011). Evaluation of acute and subchronic toxicity of Annona Muricata (Linn.) Aqueous extract in animals. European Journal of Experimental Biology 1, 115-124.

[5] Chang FR (2001). Novel cytotoxic annonaceous acetogenins from Annona muricata, Journal National Productivity 64, 925-931. http://dx.doi.org/10.1021/np010035s.

[6] Collins AJ \& Lewis DA (1971). Lysosomal enzyme level in blood of arthritic rats. Biochemistry and Pharmacology 28, 251-253. http://dx.doi.org/10.1016/0006-2952(71)90496-5.

[7] Di-Stasi LC; \& Hiruma-Lima CA (2002). Plantas Medicinais na Amazônia e na Mata Atlântica, 2nd ed.; Editora UNESP: São Paulo, Brazil 87-112.

[8] Fried MW, Duncan A, \& Soroka S (2001). Serum hyaluronic acid in patients with veno-occlusive disease following bone marrow transplantation. Bone Marrow Transplantation 27(6), 635-9. http://dx.doi.org/10.1038/sj.bmt.1702821. 
[9] George J \& Chandrakasan G (1997). Lactate dehydrogenase isoenzymes in dimethylnitrosamine induced hepatic fibrosis in rats. Journal of Clinical Biochemistry and Nutrition 22, 51-62. http://dx.doi.org/10.3164/jcbn.22.51.

[10] George J, Rao KR, Stern R, \& Chandrakasan G (2001). Dimethylnitrosamine-induced liver injury in rats: the early deposition of collagen. Toxicology 156(2-3), 129-138 http://dx.doi.org/10.1016/S0300-483X(00)00352-8.

[11] George J \& Stern R (2004). Serum hyaluronan and hyaluronidase: very early markers of toxic liver injury. Clinica. Chimica. Acta. 348, 189-197. http://dx.doi.org/10.1016/j.cccn.2004.05.018.

[12] Greige-Gerges H, Khalil RA, Chahine R, Haddad C \& Harb W (2007). Effect of cucurbitacins on bilirubin-albumin binding in human plasma. Life Sciences 80, 579-585. http://dx.doi.org/10.1016/j.lfs.2006.10.005.

[13] Halfon P, Bourliere M, \& Penaranda G (2005). Accuracy of hyaluronic acid level for predicting liver fibrosis stages in patients with hepatitis $\mathrm{C}$ virus. Complementary Hepatology 4, 6-12. http://dx.doi.org/10.1186/1476-5926-4-6.

[14] Hasegawa T, Sasaki T, Kimura T, Hoki M, Okada A, Mushiake S, Yagi M, \& Imura K (2000). Measurement of serum hyaluronic acid as a sensitive marker of liver fibrosis in biliary atresia. Journal of $\begin{array}{llll}\text { Pediatric } & \text { Surgery } & 35 & \end{array}$ http://dx.doi.org/10.1053/jpsu.2000.18342.

[15] Huang, W, Zhang J, Chua SS, Qatanani M \& Han Y (2003). Induction of bilirubin clearance by the Constitutive Androstane Receptor (CAR). PNAS 100, 4156-4161. http://dx.doi.org/10.1073/pnas.0630614100.

[16] Liaw CC, Chang FR, Lin CY, Chou CJ, Chiu HF, Wu MJ, \& Wu YC (2002). New cytotoxic monotetrahydrofuran annonaceous acetogenins from Annona muricata. Journal of National Productivity $65,470-475$. http://dx.doi.org/10.1021/np0105578.

[17] Muthulingam M, Mohandoss P, Indra N, \& Sethupathy S (2010). Antihepatotoxic efficacy of Indigofera tinctoria on paracetamolinduced liver damage in rats. International Journal of Pharmacy and Biomedical Research 1(1), 13-18.

[18] Nandan D, Venkatesan K, Katoch K, \& Dayal RS (2007). Serum beta-glucuronidase levels in children with leprosy. Leprosy Rev. 78, 243-247.

[19] Nanji AA, Tahan S R, Khwaja S, Yacoub LK \& Sadrzadeh SM (1996). Elevated plasma levels of hyaluronic acid indicate endothelial cell dysfunction in the initial stages of alcoholic liver disease in the rat. Journal of Hepatology 24, 368-374. http://dx.doi.org/10.1016/S0168-8278(96)80018-3.

[20] Nyberg A, Engstrom-Laurent A \& Loof L (1988). Serum hyaluronate in primary biliary cirrhosis--a biochemical marker for progressive liver damage. Hepatology 8(1), 142-6. http://dx.doi.org/10.1002/hep.1840080127.

[21] Ostrow JD, Pascolo L, Shapiro SM \& Tiribelli C (2003). New concepts in bilirubin encephalopathy. European Journal of ClinicalInvestment 33, 988-997. http://dx.doi.org/10.1046/j.13652362.2003.01261.x.

[22] Patel K, Lajoie A, Heaton S, Pianko S, Behling CA, Bylund D, Pockros PJ, Blatt LM, Conrad A, \& McHutchison JG (2003). Clinical use of hyaluronic acid as a predictor of fibrosis change in hepatitis C. Journal of Gastroenterology Hepatology 18, 253-257. http://dx.doi.org/10.1046/j.1440-1746.2003.02930.x.

[23] Premila A (2004). Lysosomal enzyme activity during development of Carbon tetrachloride induced cirrhosis in rats. Indian Journal of Physiology Pharmacology 48 (2), 206-212

[24] Qing-Wei H. \& Geng-Tao L. (2006). Effects of bicyclol on dimethylnitrosamine-induced liver fibrosis in mice and its mechanism of action. Life $\quad$ Sciences 606-612. http://dx.doi.org/10.1016/j.lfs.2006.02.025.

[25] Rajadurai M \& Prince PS (2007). Preventive effect of naringin on cardiac mitochondrial enzymes during isoproterenol-induced myocardial infarction in rats: a transmission electron microscopic study. Journal of Biochemistry and Molecular Toxicology 21(6), 354-61. http://dx.doi.org/10.1002/jbt.20203.

[26] Sandya S, Achan MA \& Sudhakaran PR (2007). Parallel changes in fibronectin and $\alpha_{5} \beta_{1}$ integrin in articular cartilage in type II collagen- induced arthritis. Indian Journal of Biochemistry and Biophysics 44(1), 14-18

[27] Shin M \& Moon J (2010). Effect of dietary supplementation of grape skin and seeds on liver fibrosis induced by dimethylnitrosamine in rats. Nutrition Research and Practice 4(5), 369-374. http://dx.doi.org/10.4162/nrp.2010.4.5.369.

[28] Skripenova S, Trainer TD, \& Krawitt EL (2007). Variability of grade and stage in simultaneous paired liver biopsies in patients with hepatitis C. Journal of Clinical Patholology 60(3), 321-4 http://dx.doi.org/10.1136/jcp.2005.036020.

[29] Sousa, MP, Matos MEO, Matos FJA, Machados MIL, \& Craveiro AA (2004). Constituintes Químicos Ativos e Propriedades Biológicas de Plantas Medicinais Brasileiras, 2nd ed.; Editora UFC: Fortaleza, Brazil 281-283. http://dx.doi.org/10.1023/A:1010616021659.

[30] Stickel F, Urbaschek R, Schuppan D, Poeschl G, Oesterling C, Conradt C, McCuskey RS Simanowski UA \& Seitz HK (2001). Serum collagen type VI and XIV and hyaluronic acid as early indicators for altered connective tissue turnover in alcoholic liver disease. Digest. Disease Sciences 46 (9), 2025-2032.

[31] Taylor L (2002). Graviola (Annona muricata). In Herbal Secrets of the Rainforest 2nd ed. Roseville, CA: Prima Publishing.

[32] Usunobun U \& Okolie NP (2015). Phytochemical analysis and mineral composition of Annona muricata leaves. International Journal of Research and Current Development 1(1), 38-42.

[33] Usunobun U, Okolie NP, Anyanwu OG, Adegbegi AJ \& Egharevba ME (2015). Phytochemical screening and proximate composition of Annona muricata leaves. European Journal of Botany, Plaint Science and Phytology 2(1), 18-28.

[34] Usunobun U, Okolie PN \& Eze GI (2015a). Modulatory effect of ethanolic leaf extract of Annona muricata pre-treatment on liver damage induced by Dimethylnitrosamine (DMN) in rats. British Journal of Pharmaceutical Research 8(3), 1-9. http://dx.doi.org/10.9734/BJPR/2015/19841.

[35] Usunobun U, Okolie NP, \& Eze IG. (2015b). Attenuation of N, NDimethylnitrosamine-induced liver Fibrosis in rats by ethanolic leaf extract of Annona muricata. Saudi Journal of Medical and Pharmaceutical Sciences 1(2), 62-69.

[36] Vogel AI (1971). A textbook of practical organic Chemistry including qualitative organic analysis. Longman group limited, London. Pp 426.

[37] Vrochides D, Papanikolaou V, Pertoft H, Antoniades AA, \& Heldin, P (1996). Biosynthesis and degradation of hyaluronan by nonparenchymal liver cells during liver regeneration. Hepatology 23, 1650-1655. http://dx.doi.org/10.1002/hep.510230648

[38] Wyatt HA, Dhawan A, \& Cheeseman P (2002). Serum hyaluronic acid concentrations are increased in cystic fibrosis patients with liver disease. Archive Disease and Childhealth 86(3), 190-3. http://dx.doi.org/10.1136/adc.86.3.190.

[39] Yacout GA, Elguindy NM \& El-Azab EF (2012). Hepatoprotective effect of basil (Ocimum basilicum L.) on $\mathrm{CCl}_{4}$-induced liver fibrosis in rats. Afriican Journal of Biotechnology 11(90), 15702-15711. http://dx.doi.org/10.5897/AJB11.3876. 